\title{
Single nucleotide polymorphism in Interleukin 1 alpha gene might be involved in the Oral Herpes recurrent episodes in Brazilian Para-Athletes
}

Polimorfismo de nucleotídeo único no gene Interleucina 1 alfa pode estar envolvido nos episódios de Herpes Oral recorrentes em Paratletas Brasileiros

Polimorfismo de un solo nucleótido en el gen Interleucina 1 alfa puede estar involucrado en episodios de Herpes Oral recurrentes en Paratletas Brasileños

\begin{abstract}
The main goal of this study was to investigate if there is an association between Oral Herpes (OH) recurrent episodes and Single Nucleotide Polymorphisms (SNPs) in ILIA, IL10, and ILIRN genes in a group of Brazilian Para-athletes. This transversal study was prepared according to the STrengthening the REporting of Genetic Association Studies (STREGA) guidelines. Oral examination and DNA collection for genotyping were performed in a non-probabilistic convenience sampling composed of Brazilian para-athletes who participated in a Brazilian selective competition. Data referring to the general characterization of sample were collected through a self-reported questionnaire. Candidate genes were chosen with the UCSC Genome Browser and SNPs in ILIA gene (rs17561, rs1304037), IL10 gene
\end{abstract}


(rs1800871), and ILIRN gene (rs9005) were selected and investigated in allelic, genotypic, dominant, and recessive models. Hardy-Weinberg equilibrium was evaluated in each SNP. The sample was composed of 273 para-athletes (63 (23.4\%) practice swimming, $61(22.3 \%)$ powerlifting and $145(63.7 \%)$ athletics). OH recurrent episodes was related by $47(17.2 \%)$ para-athletes and the presence of $\mathrm{T}$ allele in the rs1304037 increased chance of OH. These findings suggest that rs1304037 in IL1A gene is associated with $\mathrm{OH}$ recurrent episodes in para-athletes.

Keywords: Herpes simplex; Interleukin-1; Stomatitis, herpetic; Oral health; Para-athletes.

\begin{abstract}
Resumo
O objetivo deste estudo foi investigar se existe uma associação entre episódios de Herpes Oral recorrente (HO) e Polimorfismos de Nucleotídeo Único (SNPs) nos genes ILIA, IL10 e ILIRN em um grupo de paratletas Brasileiros. Este estudo transversal foi elaborado de acordo com as diretrizes do STrengthening the Reporting of Genetic Association Studies (STREGA). O exame bucal e a coleta de DNA para genotipagem foram realizados em uma amostra não probabilística de conveniência composta por paratletas brasileiros que participaram de uma competição seletiva. Os dados referentes à caracterização geral da amostra foram coletados por meio de questionário autorreferido. Os genes candidatos foram escolhidos com o navegador do genoma UCSC e os SNPs no gene IL1A (rs17561, rs1304037), IL10 (rs1800871) e IL1RN (rs9005) foram selecionados e investigados em modelos alélicos, genotípicos, dominantes e recessivos. O equilíbrio de Hardy-Weinberg foi avaliado para cada SNP. A amostra foi composta por 273 paratletas $(63(23,4 \%)$ praticantes de natação, $61(22,3 \%)$ levantamento de peso e $145(63,7 \%)$ de atletismo). Episódios HO recorrentes foram relatados por $47(17,2 \%)$ dos paratletas e a presença do alelo $\mathrm{T}$ no polimorfismo rs1304037 aumentou a chance de HO. Esses achados sugerem que o polimorfismo rs1304037 no gene $I L 1 A$ está associado com episódios recorrentes de $\mathrm{HO}$ em paratletas.
\end{abstract}

Palavras-chave: Herpes simples; Interleucina-1; Estomatite herpética; Saúde bucal; Paratletas.

\title{
Resumen
}

El objetivo de este estudio fue investigar si existe una asociación entre los episodios de herpes oral recurrentes (HO) y los polimorfismos de nucleótido único (SNP) en los genes IL1A, IL10 e IL1RN en un grupo de paratletas brasileños. Este estudio transversal se llevó a cabo de acuerdo con las directrices del STrengthening the Reporting of Genetic Association Studies (STREGA). El examen oral y la recolección de ADN para la genotipificación se realizaron en una muestra de conveniencia no probabilística compuesta por paratletas brasileños que participaron en una competencia selectiva. Los datos sobre la caracterización general de la muestra se recogieron a través de un cuestionario autoinformado. Los genes candidatos se eligieron con el navegador del genoma UCSC y los SNPs en el gen IL1A (rs17561, rs1304037), IL10 (rs1800871) e IL1RN (rs9005) se seleccionaron e investigaron en modelos alélicos, genotípicos, dominantes y recesivos. Se evaluó el equilibrio de Hardy-Weinberg para cada SNP. La muestra estuvo formada por 273 paratletas $(63(23,4 \%)$ natación, 61 (22,3\%) levantamiento de pesas y $145(63,7 \%)$ atletismo. 47 $(17,2 \%)$ de los paratletas informaron episodios recurrentes de $\mathrm{HO}$ y la presencia del alelo $\mathrm{T}$ en el polimorfismo rs1304037 aumentó la probabilidad de HO. Estos hallazgos sugieren que el polimorfismo rs1304037 en el gen IL1A está asociado con episodios de HO recurrentes en paratletas.

Palabras clave: Herpes simple; Interleucina-1; Estomatitis herpética; Salud bucal; Paratletas.

\section{Introduction}

Para-athletes are individuals who have a physical or intellectual impairment and perform some physical activity regularly and, according to the International Paralympic Committee, this term is applicable for all individuals with impairment that competes in recreational, collegiate, and/or official competitions, regardless of competition level (Tweedy \& Vanlandewijck, 2011; Tweedy et al., 2014; Ravensbergen et al., 2016). No doubt, the sports practice reaps significant health benefits to the para-athlete improving their physiological and psychological balance, mental wellbeing, and increasing selfconfidence, self-acceptance, respect, equality and contributing to interpersonal relationships (McConkey et al., 2013; Shapiro \& Malone, 2016). On the other hand, despite all benefits of sports practice, when a para-athlete (or athlete) is training intensely, non-rare, an organic imbalance can occur and impacts their general and oral health (Gleeson, 2007).

Many oral conditions can affect individuals of all ages, are prevalent worldwide, and have historically been considered important global health burdens (Piccininni \& Fasel, 2005. Oral herpes $(\mathrm{OH})$ is an example: an estimated 3.7 billion people have $\mathrm{OH}$ infection globally (James et al., 2016). OH, is a disease caused by a Herpes Simplex Type I virus (HSV-1) and causes extreme discomfort, paresthesia, tenderness, pain, fever, gingivostomatitis, and a burning sensation in the affected 
region (Arduino \& Porter, 2008). These lesions are located around the mouth, because of this are also called orolabial, and are very common in stressful moments, like during sports competitions (Liknes, 2011; Collins \& O’Connell, 2012) and are usually triggered by stress, exposure to ultraviolet rays and immunosuppression (Minagawa et al., 2004; Peterson et al., 2019).

$\mathrm{OH}$ is a complex multifactorial condition, in which many environmental, systemic, and genetic factors play an important role in the final phenotypes (Kriesel et al., 2014). In fact, the recurrence of herpetic lesions, called cold sore, is also dependent on viral factors and mainly on the host's defense response, which involves activation of pro-inflammatory immune cells (Minami et al., 2002; Richards et al., 2003) including interleukins (Hurme et al., 2003). Previous studies showed an association between interleukin and HSV-1 recurrent infections (Minagawa et al., 2004; Richards et al., 2003; Fields et al., 2006). In this context, considering the inflammatory and genetic aspects of the $\mathrm{OH}$, genes that codified interleukin such as interleukin 1 alpha (IL1A), interleukin 110 (IL10), and interleukin 1 antagonist receptor (ILIRN) are candidate genes to be studied in $\mathrm{OH}$ recurrent episodes susceptibility. So, the main goal of this study was to investigate if there is an association between $\mathrm{OH}$ episodes and Single Nucleotide Polymorphisms (SNPs) in ILIA, IL10, and ILIRN genes in a group of Brazilian Para-athletes.

\section{Methodology}

\subsection{Ethical Approval, Type of Study, and Sampling}

This is a transversal study that was approved by the local Ethics and Research Committee (\#3.261.377) following resolution 466/12 of the National Health Commission and was prepared according to the STrengthening the REporting of Genetic Association Studies (STREGA) guidelines (Little et al., 2005). Appropriate written informed consent was obtained from all participants and legal guardians when the para-athlete is underage. A non-probabilistic convenience sampling composed by para-athletes was used. The para-athletes were selected during Brazilian selective competition organized by the Brazilian Paralympic Committee in April 2019, in Curitiba, Paraná, Brazil. The criteria of grouping para-athletes in each sport were determined by the Brazilian Paralympic Committee according to International Standard for Eligible Impairments guidelines and, in this study, we selected para-athletes who participated in athletics, powerlifting, and swimming. Additional exclusion criteria were para-athletes who have a diagnosis of mental disorder or severe intellectual disability that non-enables them to understand and answer a questionnaire or that makes DNA sample collection impossible and genetic syndromes.

\subsection{Non-clinical data collection}

Data referring to the general characterization of the para-athletes were collected through a self-reported questionnaire in the Portuguese language that was previously described in von Held et al. (2021). The questionnaire addressed gender, age, ethnicity, school education, sport and inquired the participant about $\mathrm{OH}$ lesions and $\mathrm{OH}$ recurrent episodes. All individuals that were not sure about their answers were excluded from the survey.

\subsection{Clinical data collection}

A team composed of previously trained dentists and note-takers performed the para-athletes' oral examination. The calibration process was coordinated by an experienced examiner in epidemiological surveys (Gold-Standard) who guided the conduct of the theoretical and practical training steps. Kappa value after calibration was higher than 0.90 indicating a high degree of data reproducibility. The examination was conducted with the para-athletes seated in a chair, using natural light, tongue depressors, and gauze. 


\subsection{DNA sample collection and Genotyping}

Genomic DNA for genotyping analysis was extracted from buccal cells isolated from saliva as previously described and established (Küchler et al., 2012). The amount and purity of the DNA were determined by a spectrophotometer (Nanodrop 1000; Thermo Scientific, Wilmington, DE). Candidate genes were chosen with the UCSC Genome Browser website to identify previously characterized SNPs for each candidate gene, according to their possible function regulation and alleles frequency. A total of 4 SNPs in ILIA gene (rs17561, rs1304037), IL10 gene (rs1800871) and IL1RN gene (rs9005) were selected and investigated. The characteristics of the selected SNPs are presented in table 1.

Genotyping was performed using TaqMan SNP Genotyping Assays (Life Technologies TM) in Stratagene Mx3005P (Agilent Technologies). The real-time PCR reactions were performed in a total volume of $3 \mathrm{~mL}$ (4 ng DNA/reaction, $1.5 \mathrm{~mL}$ Taqman PCR master mix, and 0.075 SNP assay, Applied Biosystems). The thermal cycling was performed by starting with a hold cycle of $95^{\circ} \mathrm{C}$ for 10 minutes followed by 45 amplification cycles of $92^{\circ} \mathrm{C}$ for 15 seconds and $60^{\circ} \mathrm{C}$ for 1 minute. Assays and reagents were supplied by Applied Biosystems (Foster City, CA, USA). All examiners at the laboratory were blinded to the samples' group assignment. Hardy-Weinberg equilibrium was evaluated using the chi-square test within each SNP in each population and only the results that were in Hardy-Weinberg equilibrium were further analyzed.

\subsection{Statistical analysis}

Data were analyzed using the Epi Info 3.5.7 and Stata software (StataCorp, College Station, TX, USA, version 11). The study-dependent variable was oral herpes. The odds ratio (OR) and the Chi-square test were used to assess whether the allelic and/or genotypic profile in the conventional, dominant, or recessive model. An alpha of 0.05 was considered statistically significant.

\section{Results}

The studied population was composed of 273 para-athletes, 46 adolescents (16.8\%), and 227 young or adults (82.7\%). Only one individual was considered elderly. Ninety-four (30.7\%) were females, while 179 (65.5\%) were males. Regarding the ethnicity, 152 (55.7\%) were white, 117 (43.1\%) were African descendent, 1 (0.4\%) was Asian and $2(0.8 \%)$ were indigenous. About the school education, $71(26.0 \%)$ attended elementary school, $131(47.9 \%)$ attended high school and $71(26.0 \%)$ attended college. Regarding OH recurrent episodes, 47 (17.2\%) self-reported OH recurrent episodes and 219 (80.2\%) paraathletes did not show this recurrence. Regarding the sport, 63 (23.4\%) practice swimming, 61 (22.3\%) powerlifting, 145 $(63.7 \%)$ athletics. These data are showing in Table 2.

All studied SNPs were in Hardy-Weinberg equilibrium and the $\mathrm{HW}_{\text {chi-squared }}$ for rs17561, rs1304037, rs1800871, and 9005 were $1.53,0.005,0.041$, and 0.008 , respectively. The genotyping and allele distributions are presented in the Table 3 . The rs1304037 in the ILIA showed a significant association in the allelic model $(\mathrm{p}=0.05)$ in which para-athletes with $\mathrm{T}$ allele, had increased chance of OH [Odds Ratio= 1.7 (Confidence Interval 95\%= 1.0-2.9)]. 
Table 1 - Single nucleotide polymorphisms selected for this study.

\begin{tabular}{|c|c|c|c|c|}
\hline Gene (SNP) & Position & $\begin{array}{l}\text { SNP } \\
\text { type }\end{array}$ & $\begin{array}{l}\text { Ref SNP } \\
\text { Alleles }\end{array}$ & MAF \\
\hline IL1A (rs17561) & Chr.2 & Missense Mutation & $\mathrm{A} / \mathrm{C}$ & $A=0.269$ \\
\hline IL1A (rs1304037) & Chr.2 & $\begin{array}{l}\text { Transition Substitution, } \\
\text { UTR 3, Intragenic }\end{array}$ & $\mathrm{C} / \mathrm{T}$ & $\mathrm{C}=0.311$ \\
\hline IL10 (rs1800871) & Chr.1 & Intron & $\mathrm{A} / \mathrm{G}$ & $\mathrm{A}=0.312$ \\
\hline IL1RN (rs9005) & Chr.2 & UTR 3, Transition Substitution, Intragenic & $\mathrm{A} / \mathrm{G}$ & $\mathrm{A}=0.274$ \\
\hline
\end{tabular}

Source: Obtained from databases: http://www.thermofisher.com; http://www.ncbi.nlm.nih.gov and http://genome.ucsc.edu

Table 2 - Demographic characteristics of study population and frequency of $\mathrm{OH}$.

\begin{tabular}{|c|c|c|c|c|}
\hline & $\mathrm{N} ; \%$ & $\mathrm{OH}$ & $\mathrm{N}(\%)$ & p-value \\
\hline \multirow{4}{*}{ Gender } & \multirow[t]{2}{*}{ Male $(179 ; 65.5)$} & Unaffected & $148(67.5)$ & \multirow{4}{*}{0.43} \\
\hline & & Affected & $29(61.7)$ & \\
\hline & \multirow[t]{2}{*}{ Female $(94 ; 30.7)$} & Unaffected & $71(32.4)$ & \\
\hline & & Affected & $18(38.3)$ & \\
\hline \multirow{4}{*}{ Age } & \multirow[t]{2}{*}{ Adolescents (under 19 years old) $(46 ; 16.8)$} & Unaffected & $9(20.5)$ & \multirow{4}{*}{0.59} \\
\hline & & Affected & $35(79.5)$ & \\
\hline & \multirow[t]{2}{*}{ Higher than 19 years old $(227 ; 82.7)$} & Unaffected & $38(17.1)$ & \\
\hline & & Affected & $184(82.9)$ & \\
\hline \multirow{8}{*}{ Ethnicity } & \multirow[t]{2}{*}{ White $(152 ; 55.7)$} & Unaffected & $118(53.9)$ & \multirow{8}{*}{0.67} \\
\hline & & Affected & $28(59.6)$ & \\
\hline & \multirow[t]{2}{*}{ African descendent $(117 ; 43,1)$} & Unaffected & $98(32.8)$ & \\
\hline & & Affected & $19(23.4)$ & \\
\hline & \multirow[t]{2}{*}{ Asian $(1 ; 0.4)$} & Unaffected & $1(0.4)$ & \\
\hline & & Affected & $0(0.0)$ & \\
\hline & \multirow[t]{2}{*}{ Indigenous $(2 ; 0.8)$} & Unaffected & $2(0.9)$ & \\
\hline & & Affected & $1(2.1)$ & \\
\hline \multirow{6}{*}{$\begin{array}{c}\text { School } \\
\text { education }\end{array}$} & \multirow[t]{2}{*}{ Elementary school $(71 ; 26.0)$} & Unaffected & $58(26.4)$ & \multirow{6}{*}{0.19} \\
\hline & & Affected & $10(21.2)$ & \\
\hline & High school $(131 ; 47.9)$ & Unaffected & $99(45.2)$ & \\
\hline & & Affected & $28(59.5)$ & \\
\hline & \multirow[t]{2}{*}{ College or higher $(71 ; 26.0)$} & Unaffected & $62(28.3)$ & \\
\hline & & Affected & $9(19.1)$ & \\
\hline \multirow{6}{*}{ Sports } & \multirow[t]{2}{*}{ Swimming $(63 ; 23.4)$} & Unaffected & $51(23.4)$ & \multirow{6}{*}{0.37} \\
\hline & & Affected & $12(25.5)$ & \\
\hline & \multirow[t]{2}{*}{ Powerlifting $(61 ; 22.3)$} & Unaffected & $43(19.7)$ & \\
\hline & & Affected & $14(29.8)$ & \\
\hline & \multirow[t]{2}{*}{ Athletics $(145 ; 63.7)$} & Unaffected & $124(56.4)$ & \\
\hline & & Affected & $21(44.7)$ & \\
\hline
\end{tabular}

Source: Authors. 
Table 3 - Genotype and allelic distribution according to oral herpes in the para-athletes.

\begin{tabular}{|c|c|c|c|c|c|c|c|c|c|}
\hline Gene & rs\# & Groups & \multicolumn{3}{|c|}{ Genotype n (\%) } & $\begin{array}{c}\mathrm{p}- \\
\text { value }\end{array}$ & \multicolumn{2}{|c|}{ Allele } & $\begin{array}{c}\mathrm{p}- \\
\text { value }\end{array}$ \\
\hline \multicolumn{10}{|c|}{ Oral Herpes } \\
\hline \multirow{6}{*}{ IL1A } & & & $\mathbf{A A}$ & $\mathrm{AC}$ & $\mathrm{CC}$ & & $\mathbf{A}$ & $\mathbf{C}$ & \\
\hline & \multirow[t]{2}{*}{17561} & Unaffected & $19(10.3)$ & $65(35.3)$ & $100(54.4)$ & \multirow[t]{2}{*}{0.28} & $103(28.0)$ & $265(72.0)$ & \multirow[t]{2}{*}{0.31} \\
\hline & & Affected & $1(2.5)$ & $16(40.0)$ & $23(57.5)$ & & $18(22.5)$ & $62(77.5)$ & \\
\hline & & & $\mathrm{CC}$ & CT & TT & & $\mathbf{C}$ & $\mathbf{T}$ & \\
\hline & \multirow[t]{2}{*}{1304037} & Unaffected & $24(11.8)$ & $90(44.3)$ & $89(43.9)$ & \multirow[t]{2}{*}{0.13} & $138(34.0)$ & $268(66.0)$ & \multirow[t]{2}{*}{0.05} \\
\hline & & Affected & $1(2.4)$ & $17(41.5)$ & $23(56.1)$ & & $19(23.2)$ & $63(76.8)$ & \\
\hline \multirow{3}{*}{ IL10 } & & & $\mathbf{A A}$ & $\mathbf{A G}$ & GG & & $\mathbf{A}$ & $\mathbf{G}$ & \\
\hline & \multirow[t]{2}{*}{1800871} & Unaffected & $37(20.0)$ & $95(51.4)$ & $53(28.6)$ & \multirow[t]{2}{*}{0.31} & $169(45.7)$ & $201(54.3)$ & \multirow[t]{2}{*}{0.16} \\
\hline & & Affected & $6(15.4)$ & $17(43.6)$ & $16(41.0)$ & & $29(37.2)$ & $49(62.8)$ & \\
\hline \multirow{3}{*}{ IL1RN } & & & $\mathbf{A A}$ & AG & GG & & $\mathbf{A}$ & $\mathbf{C}$ & \\
\hline & \multirow[t]{2}{*}{9005} & Unaffected & $19(9.5)$ & $82(41.2)$ & $98(49.2)$ & \multirow[t]{2}{*}{0.60} & $120(30.1)$ & $278(69.9)$ & \multirow[t]{2}{*}{0.41} \\
\hline & & Affected & $2(4.9)$ & $17(41.5)$ & $22(53.6)$ & & $21(25.6)$ & $61(74.4)$ & \\
\hline
\end{tabular}

Note: Bold form indicates statistical significance difference.

Source: Authors.

Table 4 the showed genotypic analysis of polymorphisms in dominant and recessive models and showed that there is no significant difference between the genetic polymorphisms in the ILIA gene (rs17561); ILIO gene (rs1800871) and IL1RN gene (rs9005) and $\mathrm{OH}$, although the rs1304037 showed borderline association $(\mathrm{p}=0.07)$ with $\mathrm{OH}$ in the dominant model $(\mathrm{TT}+$ CT).

Table 4 - Genotypic analysis of polymorphisms in dominant and recessive models.

\begin{tabular}{|c|c|c|c|c|c|c|}
\hline rs\# & Model & \multirow{4}{*}{$\begin{array}{c}\text { Groups } \\
\text { Oral Herpes } \\
\text { Unaffected } \\
\text { Affected }\end{array}$} & \multicolumn{2}{|c|}{ Genotype n (\%) } & \multirow[t]{2}{*}{ p-value } & \multirow[t]{2}{*}{ Odds Ratio } \\
\hline \multirow{6}{*}{17561} & \multirow{3}{*}{ Dominant } & & $\mathrm{CC}+\mathrm{AC}$ & $\mathbf{A A}$ & & \\
\hline & & & $165(89.7)$ & $19(10.3)$ & \multirow[t]{2}{*}{0.11} & \multirow[t]{2}{*}{$0.22(0.02-1.71)$} \\
\hline & & & $39(97.5)$ & $1(2.5)$ & & \\
\hline & & \multicolumn{2}{|r|}{$\mathbf{A A}+\mathbf{A C}$} & \multicolumn{2}{|l|}{$\mathrm{CC}$} & \\
\hline & \multirow[t]{2}{*}{ Recessive } & Unaffected & $84(45.6)$ & $100(54.4)$ & \multirow[t]{2}{*}{0.71} & \multirow[t]{2}{*}{$1.13(0.56-2.26)$} \\
\hline & & Affected & $17(42.5)$ & $23(57.5)$ & & \\
\hline \multirow{6}{*}{1304037} & & & TT + CT & $\mathrm{CC}$ & & \\
\hline & \multirow[t]{2}{*}{ Dominant } & Unaffected & $179(88.2)$ & $24(11.8)$ & \multirow[t]{2}{*}{0.07} & \multirow[t]{2}{*}{$1.18(0.02-1.41)$} \\
\hline & & Affected & $40(97.6)$ & $1(2.4)$ & & \\
\hline & & & $\mathrm{CC}+\mathrm{CT}$ & TT & & \\
\hline & \multirow[t]{2}{*}{ Recessive } & Unaffected & $114(56.2)$ & $89(43.8)$ & \multirow[t]{2}{*}{0.15} & \multirow[t]{2}{*}{$1.63(0.83-3.21)$} \\
\hline & & Affected & $18(43.9)$ & $23(56.1)$ & & \\
\hline \multirow{6}{*}{1800871} & & & $\mathbf{G G}+\mathbf{A G}$ & $\mathbf{A A}$ & & \\
\hline & \multirow[t]{2}{*}{ Dominant } & Unaffected & $148(80.0)$ & $37(20.0)$ & \multirow[t]{2}{*}{0.50} & \multirow[t]{2}{*}{$1.72(0.28-1.86)$} \\
\hline & & Affected & $33(84.6)$ & $6(15.4)$ & & \\
\hline & \multicolumn{3}{|r|}{$\mathbf{A A}+\mathbf{A G}$} & \multirow{2}{*}{$\frac{\text { GG }}{53(286)}$} & & \multirow{3}{*}{$1.73(0.84-3.53)$} \\
\hline & \multirow[t]{2}{*}{ Recessive } & Unaffected & $132(71.3)$ & & \multirow[t]{2}{*}{0.12} & \\
\hline & & Affected & $23(58.9)$ & $16(41.0)$ & & \\
\hline \multirow{6}{*}{9005} & \multirow{3}{*}{ Dominant } & & $\mathbf{G G}+\mathbf{A G}$ & $\mathbf{A A}$ & & \\
\hline & & Unaffected & $180(90.4)$ & $19(9.5)$ & \multirow[t]{2}{*}{0.92} & \multirow[t]{2}{*}{$0.48(0.10-2.17)$} \\
\hline & & Affected & $39(95.1)$ & $2(4.9)$ & & \\
\hline & & & $\mathbf{A A}+\mathbf{A G}$ & GG & & \\
\hline & Recessive & Unaffected & $101(50.7)$ & $98(49.2)$ & 0.26 & $1.19(0.60-2.34)$ \\
\hline & & Affected & $19(46.3)$ & $22(53.6)$ & & \\
\hline
\end{tabular}

Source: Authors. 


\section{Discussion}

In this transversal study we tested the hypothesis that SNPs in genes that codified interleukin such as IL1A, IL10, and $I L I R N$ are associated with $\mathrm{OH}$ recurrent episodes. For that, we collected DNA samples from 273 Brazilian para-athletes that were in a classificatory competition organized by the Brazilian Paralympic Committee and selected 4 SNPs in candidate genes to be studied. We observed that the prevalence of the $\mathrm{OH}$ recurrent episodes in the studied population was lower than the global estimative. Even so, the rs1304037 in the ILIA gene showed a marginally significant influence on OH episodes in allelic and in dominant models.

Regarding the prevalence of self-reported $\mathrm{OH}$ recurrent episodes, while the global prevalence is around $66.6 \%$ in general population (James et al., 2016), in our study, only 17.2\% of the para-athletes reported OH recurrent episodes. Although interesting, this information should be interpreted cautiously, because our study provides a snapshot picture of the $\mathrm{OH}$ prevalence at that moment, before an important competition. It is plausible that, despite the care that the researchers had in conducting the exams and applying the questionnaires, at that moment, the focus of the para-athletes was their performance in the competition and they did not make the association with perceiving signs and symptoms of the OH. So it is important to clarify that it could be an underestimate prevalence. Even with these limitations, an important result was observed: we found an association between $\mathrm{rs} 1304037$ in the ILIA gene with $\mathrm{OH}$ recurrent episodes.

At this point, it is important to mention that HSV is a human pathogen that exists in two forms: type 1 and type 2. Transmission of HSV type 2 is mainly sexual and causes genital herpes (Pinninti \& Kimberlin, 2013). Despite HSV type 1 also causes genital herpes, its mainly transmitted by oral-to-oral contact (Higgins et al., 1993) and causes infection in the skin and mucosal epithelial cells, inhibiting inflammatory pathways (Milora et al., 2014). In the active phase, causes vesicle ulcerative lesions that are usually 1-2 mm blisters and affects mainly lips and rapidly break down produces classic symptoms (Arduino \& Porter, 2008). Infected keratinocytes showed high expression of interleukins that are believed could be a signal to the recruitment of the inflammatory cells to the damaged tissue (Dinarello, 2009). After resolution of a primary infection that persist 3-10 days, the virus migrates to the trigeminal nerve ganglion, where it is capable of remaining in a latent state. Recurrent infection occurs when the individual is exposed to environmental factors (Stoopler \& Greenberg, 2003) and, in fact, even during latent state HSV-1 induces persistent expression of interleukin genes by varying a continuous source of antigenic stimulation (Baker et al., 1999), so it is natural that genes that encoding interleukin might be candidates to be studied.

In this sense, we decided to evaluate the association between genes that codified interleukin and selected SNPs rs17561, rs1304037, rs1800871, and rs9005. The first one, rs17561, represents a missense mutation leading to aminoacid change (Ala114Ser) and is a SNP target to be studied once have been associated with various inflammatory conditions (Berger et al., 2002; Liu et al., 2013)._The rs1800871 and rs9005 are SNPs extensively investigated in abnormal cell proliferation and cancer development in different stages of disease progression (Tindall et al., 2010; Niu et al., 2015; Moghimi et al., 2018). Despite involvement in the inflammatory response, in our study, it was not possible to prove the association between rs17561, rs1800871, and rs9005 with $\mathrm{OH}$ episodes in any of the analyzed genetic models. Thus, the primary conclusion is that these polymorphisms do not appear to be associated with $\mathrm{OH}$ but is important to mention that sometimes the analysis of a single allele could be inappropriate.

Regarding rs1304037, in contrast with the other studied polymorphisms, the results indicated that rs1304037 was associated with $\mathrm{OH}$ episodes. In fact, our result suggests that allele $\mathrm{T}$ in affected para-athletes increased the risk of $\mathrm{OH}$ episodes and TT+CT genotypes are borderline for this condition. Similarly, this allelic variation was associated with chronic spontaneous urticaria (Moghimi et al., 2018). Is important to mention that this SNP is located in the 3'-untranslated region of the gene and SNPs in this region could be involved in gene expression variations consequently with important biological 
impacts (Johnsen et al., 2008; Badie et al., 2020) but to the best of our knowledge, this seems to be the first research paper linking the genetic polymorphism in the $I L-1$ in the context of the pathogenesis of OH. Furthermore, another point that needs to be considered is the possible interactions of these four SNPs as contributed for OH. In fact, an analysis based on haplotypes or diplotypes in this population remains necessary.

\section{Conclusion}

This study provides new insight into the genetics contribution for $\mathrm{OH}$ episodes and showed that single nucleotide polymorphism 1304037, allele T, in ILIA gene may confer an increased risk for the susceptibility to OH episodes in paraathletes.

\section{Acknowledgments}

This study received financial and material support from Universidade Positivo, FAPERJ - Fundação de Amparo à Pesquisa do Estado do Rio de Janeiro, Grant/Award Number: \#E-26/010.002195/2019; CAPES-Coordenação de Aperfeiçoamento de Pessoal de Nível Superior; CNPQ-Conselho Nacional de Desenvolvimento Científico e Tecnológico; FOPESQ/UFF and by the Brazilian Paralympic Committee.

\section{References}

Arduino, P. G. \& Porter, S. R. (2008). Herpes Simplex Virus Type 1 Infection: Overview on Relevant Clinico-Pathological Features. J Oral Pathol Med, 37, 107-121. doi.org/10.1111/j.1600-0714.2007.00586.x

Badie, A., Saliminejad, K., Salahsourifar, I. \& Khorshid, H. R. K. (2020). Interleukin 1 alpha (IL1A) polymorphisms and risk of endometriosis in Iranian population: a case-control study. Gynecol Endocrinol, 36(2),135-138. 10.1080/09513590.2019.1631790.

Baker, M., Noisakran, S., Gebhardt, B. M., Kriesel, J. D. \& Carr, D. J. J. (1999). The Relationship between Interleukin-6 and Herpes Simplex Virus Type 1: Implications for Behavior and Immunopathology. Brain, Behavior, and Immunity, 13, 201-211.

Berger, P., McConnell, J. P., Nunn, M., Kornman, K. S., Sorrel, J., Stephenson K., Duff, G. W. (2002) C reactive protein levels are influenced by common IL1 gene variations. Cytokine, 17(4), 171-174.

Brzoza, Z., Rymarczyk, B., Grzeszczak, W., Trutsolt, W., Pluta-Kubicz, M. \& Moczulski, D. (2020). Interleukin 1 Gene Polymorphisms Presumably Participate in the Pathogenesis of Chronic Spontaneous Autoreactive Urticaria. Journal of Interferon \& Cytokine Research. 2020, 40(10) doi.org/10.1089/jir.2020.0103

Collins, C. J. \& O’Connell, B. (2012). Infectious Disease Outbreaks in Competitive Sports, 2005-2010. J Athl Train, 47, 516-518. doi.org/10.4085/1062-605047.5.02.

Dinarello, C. A. (2009). Immunological and inflammatory functions of the interleukin-1 family. Annu Rev Immunol, 27, 519-550

Fields, M., Zheng, M., Zhang, M. \& Atherton, S. S. (2006). Tumor necrosis factor alpha and macrophages in the brain of herpes simplex virus type 1-infected BALB/c mice. J Neuro Virol, 12, 443-455.

Gleeson, M. (2007). Immune function in sport and exercise. J Appl Physiol, 103, 693-699.

Higgins, C. R., Schofield, J. K., Tatnall, F. M. \& Leigh, I. M. (1993). Natural history, management and complications of herpes labialis. J Med Virol, 41(1), 22-26. http://dx.doi.org/10.1002/jmv.1890410506 PMID: 8245888

Hurme, M., Haanpa, M., Nurmikko, T., Wang, X. Y., Virte, M., Pessi, T., Kilpinen, S., Hulkonen, J. \& Helminen, M. (2003) IL-10 Gene Polymorphism and Herpes virus Infections. J Med Virol, 70, 48-50.

International Paralympic Committee. International Standard for Eligible Impairments. Available https://www.paralympic.org/sites/default/files/document/161007092455456 Accessed 14 september 2021

James, C., Harfouche, M., Welton, N. J., Turner, K. M. E., Abu-Raddad, L. J., Gottlieb, S. L. \& Looker, K. J. (2020). Herpes simplex virus: global infection prevalence and incidence estimates, 2016. Bull World Health Organ, 98, 315-329 http://dx.doi.org/10.2471/BLT.19.237149

Johnsen, A. K., Plenge, R. M., Butty, V., Campbell, C., Diegue-Gonzalez, R. D., Gomez-Reino, J. J., Shadick, M. D., Weinblatt, M., Gonzalez, A., Gregersen, P. K., Benoist, C. \& Mathis, D. (2008). A broad analysis of IL1 polymorphism and rheumatoid arthritis. Arthritis Rheum, 58(7), 1947-1957. $10.1002 /$ art.23592. 
Kriesel, J. D., Bhatia, A. \& Thomas, A. (2014). Cold sore susceptibility gene-1 genotypes affect the expression of herpes labialis in unrelated human subjects. Human Genome Variation, 1, 14024, 1-6. 10.1038/hgv.2014.24.

Küchler, E. C., Tannure, P. N., Falagan-Lotsch, P., Lopes, T. S., Granjeiro, J. M. \& Amorim, L. M. F. (2012). Buccal cells DNA extraction to obtain high quality human genomic DNA suitable for polymorphism genotyping by PCR-RFLP and Real-Time PCR. J Appl Oral Sci, 20(4), 467-471. https://doi.org/10.1590/S1678-77572012000400013

Liknes, L. P. (2011). Common Dermatologic Infections in Athletes and Return-to-Play Guidelines. J Am Osteopath Assoc, 111, 373-379. doi.org/10.7556/jaoa.2011.111.6.373.

Little, J., Higgins, J. P. T., Ioannidis, J. P. A., Moher, D., Gagnon, F., von Elm, E., Khoury, M. J., Cohen, B., Davey-Smith, G., Grimshaw, J., Scheet, P., Gwinn, M., Williamson, R. E., Zou, G. Y., Hutchings, K., Johnson, C. Y., Tait, V., Wiens, M., Golding, j., van Duijn, C., Mclaughlin, J., Paterson, A., Wells, G., fortier, I., Freedman, M., Zecevic, M., King, R., Infante-Rivard, C., Stewart, A. \& Birkett, N. (2009). STrengthening the REporting of Genetic Association studies (STREGA): an extension of the STROBE Statement. Ann Intern Med, 3, 150(3), 206-215.

Liu, Y., Li, S., Zhang, G., Nie, G., Meng, Z., Mao, D., Chen, C., Chen, X., Zhou, B \& Zeng, G. (2013). Genetic variants in IL1A and IL1B contribute to the susceptibility to 2009 pandemic H1N1 influenza A virus. BMC Immunology, 14(37). 10.1186/1471-2172-14-37.

McConkey, R., Dowling, S., Hassan, D. \& Menke, S. (2013). Promoting social inclusion through Unified Sports for youth with intellectual disabilities: a fivenation study. J of Intellectual Disability Res, 57(10), 923-935.

Milora, K.A., Miller, S.L., Sanmiguel, J.C. \& Jensen, L.E. (2014). Interleukin-1 $\alpha$ released from HSV-1 infected keratinocytes act as a functional alarmin in the skin. Nat Commun, 5, 5230. 10.1038/ncomms6230.

Minagawa, H., Hashimoto, K. \& Yanagi, Y. (2004). Absence of tumor necrosis factor facilitates primary and recurrent herpes simplex virus-1 infections. $J$ Gen Virol, 85, 343-347.

Minami, M., Kita, M., Yan, X. Q., Yamamoto, T., Iida, T., Sekikawa, K., Iwakura, Y. \& Imanishi, J. (2002). Role of IFN-gamma and tumor necrosis factoralpha in herpes simplex virus type 1 infection. J Interferon Cytokine Res, 22(6), 671-676. 10.1089/10799900260100150

Moghimi, M., Ahrar, H., Karimi-Zarchi, M., Aghili, K., Salari, M., Zare-Shehneh, M. \& Neamatzadeh, H. (2018). Association of IL-10 rs1800871 and rs1800872 Polymorphisms with Breast Cancer Risk: A Systematic Review and Meta-Analysis. Asian Pacific Journal of Cancer Prevention, 19, 3353-3359. 10.31557/APJCP.2018.19.12.3353.

Niu, Y.M., Du, X. Y., Cai, H. X., Zhang, C., Yuan, R. X., Zeng, X. T. \& Luo, J. (2015). et al. Increased risks between Interleukin-10 gene polymorphisms and haplotype and head and neck cancer: a meta-analysis. Sci Rep, 5, 17149, 1-10.

Peterson, A. R., Nash, E. \& Anderson, B. J. (2019). Infectious Disease in Contact Sports. Sports Health, 11, 47-58. doi.org/10.1177/1941738118789954.

Piccininni, P. M. \& Fasel, R. (2005). Sports dentistry and the Olympic Games. J Can Dent Assoc, 33, 471-483.

Pinninti, S. G. \& Kimberlin, D. W. (2013). Maternal and neonatal herpes simplex virus infections. Am J Perinatol, 30(2):113-20. http://dx.doi.org/10.1055/s0032-1332802 PMID: 23303485

Ravensbergen, H. J., Mann, D. L. \& Kamper, S. J. (2016). Expert consensus statement to guide the evidence-based classification of paralympic athletes with vision impairment: a Delphi study. Br. J. Sports Med, 50, 386-391. 10.1136/bjsports-2015-095434.

Richards, C. M., Case, R., Hirst, T. R., Hill, T. J. \& Williams, N. A. (2003). Protection against recurrent ocular herpes simplex virus Type 1 disease after therapeutic vaccination of latently infected mice. $J$ virol, 77, 6692-6699.

Shapiro, D. R. \& Malone, L. A. (2016). Quality of life and psychological affect related to sport participation in children and youth athletes with physical disabilities: A parent and athlete perspective. Disability and Health Journal, 9(3), 385-391.

Stoopler, E. T. \& Greenberg, M. S. (2003). Update on herpes virus infections. Dent Clin North Am, 47(3), 517-532.

Tindall, E. A., Hayes, V. M. \& Petersen, D. C. (2010). Inflammatory Genetic Markers of Prostate Cancer Risk. Cancers, 2, 1198-1220, $10.3390 /$ cancers 2021198

Tweedy, S. M., Beckman, E. M. \& Connick, M. J. (2014). Paralympic classification: conceptual basis, current methods, and research update. PM\&R, 6, S11S17. 10.1016/j.pmrj.2014.04.013

Tweedy, S. M. \& Vanlandewijck, Y. C. (2011). International paralympic committee position stand-background and scientific principles of classification in Paralympic sport. Br. J. Sports Med, 45, 259-269. 10.1136/ bjsm.2009.065060

von Held, R., Castilho, T., Antunes, L. A. A., Tavares, J. S., Petinati, M. F. P., Winckler, C., Oliveira Neto, Z. C., Scariot, R., Kuchler, E. C., Brancher, J. A. \& Antunes, L. S. (2021). Interleukin 1 alpha genetic polymorphisms as potential biomarkers for oral health-related quality of life in Para athletes. Spec Care Dentist, 10, 1-9. 10.1111/scd.12627 